$551.8(477.8)$

\author{
• огуцький, . митрук, . ум с \\ ьвівський н ціон льний університет імені в н \\ вул. . орошенк, 41, м. ввів, 79000, кр їн
}

ведено н ліз основних літолого-петрогр фічних х р ктеристик дубнівського викопного грунтового комплексу н території лицького ридністер'я. підст ві м л кологічного н лізу проведено реконструкцію природних умов ч су утворення викопного грунту. ро н лізов но приуроченість культурних ш рів верхнього п леоліту до дубнівського викопного грунту т н ддубнівського соліфлюкційного підгоризонту.

лючові слов : викопний грунт, лицьке ридністер'я, п леоліт, соліфлюкція, м л коф ун .

ьогодні р йон лицького ридністер'я (рис. 1) вивч ють як комплексний геологогеоморфологічний т рхеологічний об’єкт. ослідження плейстоценових відкл дів, їхній н ліз, кореляція, відтворення п леогеогр фічних умов д ють змогу розкрити нові фізико-геогр фічні спекти поселення т прожив ння д вніх людей н цій території.

ей $\mathrm{p}$ йон є одним з н йб г тших у хідній вропі з кількістю п леолітичних п м'яток.

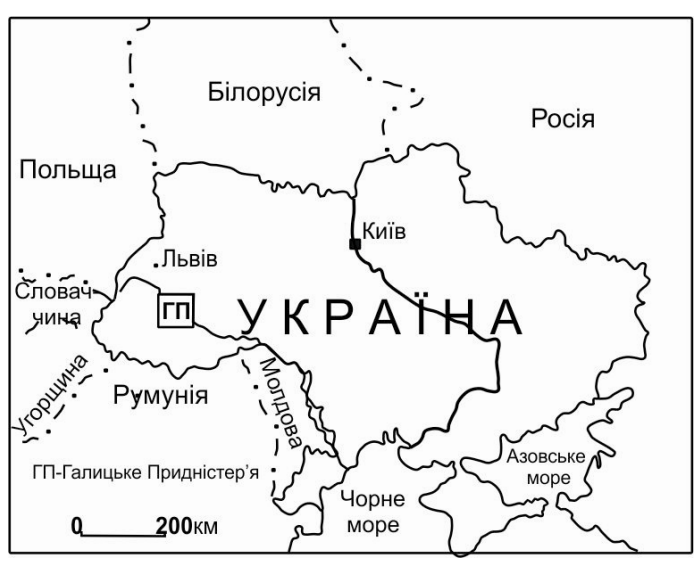

ис. 1. озміщення р йону лицьке ридністер'я.

убнівський викопний грунт сформов ний упродовж одного 3 н йтепліших інтерст ді лів верхнього плейстоцену. тр тигр фічн витрим ність т будов викопного грунту д є підст ви розгляд ти його як в жливий м ркув льний горизонт верхньоплейстоценової лесово-грунтової серії. ме до цього грунту приурочені н йд вніші культурні горизонти пізнього п леоліту у лицькому ридністер'ї.

() огуцький ., митрук ., ум с ., 2011 
ерхньоплейстоценові відкл ди н території хідної кр їни з г лом і лицького ридністер'я зокрем вивч ло б г то дослідників. собливу ув гу в рто звернути н дослідження . еличк [6], . в нової, . отуз , . убіної [10], . оліховської [5] т ін. кінця 80-х років лицьке ридністер'я ст є територією комплексного дослідження ф хівців різних г лузей. ослідження проводять . огуцький, . цишин, . нчонт, . дейськ, . вроцький, . усяк т ін. $[2-4,10]$. еконструкції п леогеогр фічних умов н підст ві викопної ф уни молюсків провели . митрук т . лекс ндровіч [9]. соблив ув г до вивчення цієї території посилил сь з огляду н відкриття зн чної кількості п леолітичних п м'яток. он д 15 років тут проводяться систем тичні рхеологічні дослідження під керівництвом итник $[2,4,8]$.

убнівський викопний грунт з фіксов ний у верхньоплейстоценових лес х (між нижнім т верхнім горизонтом верхньоплейстоценових лесів) [10], відповід є одному 3 н йбільш вир жених потеплінь у ч с верхньоплейстоценового зледеніння. формув вся грунт упродовж третьої киснево-ізотопної ст дії [10], корелює з брянським п леогрунтом [6, с. 73] т віт чівським горизонтом у стр тигр фічній схемі [7, с.219]. геологічних розріз х дубнівський викопний грунт добре виділяється з вдяки чіткій будові, з б рвленню, різкому язикув тому нижньому конт кту гумусового горизонту (що не вл стиво, н прикл д, горохівському викопному грунтовому комплексу) [6, с. 74] т іншим особливостям.

убнівський викопний грунт виявлений у серії розрізів т з чисток н досліджув ній території. ижче н ведемо короткі описи тих відслонень, де з грунтом т соліфлюкційною п чкою, що з ляг є вище, пов'яз ні зн хідки п леоліту т ф уни молюсків.

леолітичн стоянк лич розт шов Н н пр ктично н йвищій ч стині привододільного схилу ( лич-гор ), що у м. лич, відкрит н прикінці 1980-х, комплексні геолого- рхеологічні дослідження поч ли проводити з кінця 1990-х років. ут дубнівський викопний грунт з ляг є н глибині 2,5-3,0 м. кл дений він суглинк ми, які сл бко з кип ють з соляною кислотою. п чці тр пляються гнізд зі скупченням ул мків вугликів. углинки дубнівського грунту червонув то-коричневі, м кропористі, із вторинними к рбон т ми, плям ми оглеєння (до 5 см), чорними кр пковими і більшими (до 3 мм) з лізисто-м нг новими новоутвореннями. ижній конт кт п чки чіткий, хвилястий (рис. 2) [10].

леолітичн стоянк лич розміщен н відст ні 60-100 м від п леолітичної п м'ятки лич нижче по схилу. н прямі схилу добре стр тифіков ні відкл ди верхнього плейстоцену є ч стково денудов ними, включ ючи горохівський викопний грунтовий комплекс, у цьому р зі спостеріг ють н рост ння потужності делюві льно-соліфлюкційної п чки. глибині 2,75-3,05 м з ляг є горизонт, який, імовірно, є соліфлюкційно деформов ним дубнівським грунтом. овщ суглинист, бл китно-сірого кольору, з чіткими лінз ми т гнізд ми п левого лесу потужністю до $20 \mathrm{cm.}$ лінзи темнішого м тері лу, тр пляється т кож 6 г то з лізисто-м нг нових конкрецій до 3,0 см ді метром [4].

2007 р. 3 чищено потужний (пон д 13 м) геологічний розріз лич $\quad$ (див. рис. 2), у якому предст влені пр ктично всі виявлені н цій території стр тигр фічні горизонти т підгоризонти верхнього плейстоцену. 3 чистці дубнівський грунт тут м $є$ двоскл дову будову і з ляг є в ді п зоні глибин 7,40-8,45 м. ижче н ведено короткий опис досліджув ної п чки:

7,40-7,75 м верхній викопний грунт, скл дений супіск ми голубув то-сірими з бурим відтінком через оз лізнення (7,5 YR 7/2). упіски дуже оглеєні, переповнені пух- 
кими з лізисто-м нг новими новоутвореннями перев жно бурими, місцями плек тивнодеформов ні, з новоутвореннями типу кілець ізег нг . ижній конт кт ясний, з зміною кольору;

7,75-8,0 м лесовий горизонт змінної потужності (до 30 см м ксим льно). еси к рбон тні, супіш ні, п леві (7,5 YR 8/3), досить однорідні, в лес х є псевдоміцелій, невеликі (до 1 см) к рбон тні стяжіння, кр пкові т конкреційні з лізисто-м нг нові новоутворення до 3 мм у ді метрі. ижній конт кт дуже чіткий, нерівний;

8,0-8,45 м нижній грунт скл дений к рбон тними супіск ми 3 псевдоміцелієм, весь плик тивно деформов ний, в деяких місцях розбитий клиноподібними невеликими структур ми, які йдуть із міждубнівського лесу, шириною до 15 см, і, очевидно, кріогенного походження, тому що відгин ють н конт кті породи до верху, х р ктерною озн кою супісків цього грунту є оз лізнення, горизонт льно-хвилясті смуги якого добре виділяють плик тивну деформов ність, є т кож велик кількість з лізисто-м нг нових новоутворень, головно чорних. ижній конт кт чіткий з зміною кольору [3].

о дубнівського викопного грунту приурочені зн хідки верхнього п леоліту стоянки ежсиіриі. есовий покрив у р йоні стоянки м є змінну потужність - від 4 до 10 м. пис профілю був викон ний у 1999 р. [10]. ут дубніський викопний грунт з ляг є н глибині 3,75-3,90 м. е оглеєний горизонт, супіщ ний, у ш рі н явні численні форми вторинних к рбон тів (конкреції, псевдоміцелій), т кож м нг ново-з лізисті конкреції до 3 см у ді метрі; з $\mathrm{HCl}$ вз ємодіє. ижня меж ясн , хвиляст , зі смуг ми оз лізнення, місцями й орштейн ми до 1 см у поперечнику. ляг є н супіщ ному нижньому горизонті верхньоплейстоценових лесів.

околицях смт зупіль сьогодні відкрито декільк п леолітичних стоянок, що зумовило дослідження низки геологічних профілів. йд внішою є відкрит в 1989 р. п м'ятк зупіль [2]. м розріз розт шов ний н пр вому березі р. ністер (невеликий мис третьої н дз пл вної тер си), з 1,6 км від північних околиць смт зупіль. я п м'ятк унік льн 3 вдяки чіткості стр тигр фічних умов 3 ляг ння. ут верхньоплейстоценові леси розділені стр тигр фічно в жливим дубнівським грунтом, ч с формув ння якого оцінюють близько 40,0 55,0 тис. років тому [10] (д тов но термолюмінесцентним методом у л бор торії університету рії юрі- клодовської, м. юблін, ольщ ). убнівський викопний грунт 3 ляг є н глибині 1,85-2,75 м і м є вир жений генетичний профіль.

оризонт (гумусовий) потужністю 0,2-0,3 м. кл дений суглинк ми сірув то-коричневими, що повсюдно перероблені червоточин ми ді метром до 2,0 см. углинки однорідні, містять суч сні кротовини ді метром до 10,0 см, які з повнені лес ми і м тері лом горизонту суч сного грунту, перехід поступовий.

оризонт (ілюві льний) потужністю 0,6-0,7 м. кл дений суглинк ми жовтув токоричневими, з червонув тим відтінком, щільними, м кропористими, безк рбон тними. ля ш ру х р ктерн н сиченість з лізисто-м нг новими конкреціями ді метром до 3,0 мм. ерехід з зміною кольору, ясний.

ме до гумусного горизонту цього грунту приурочений верхньоп леолітичний культурний ш $\mathrm{p}$.

тоянк зупіль відкрит н весні 2005 р., досліджен у п’яти розкоп х. озт шов н стоянк зупіль . цьому місці третя тер с піднім ється н д урізом води н 15-16 м. убнівський викопний грунт добре предст влений у розкоп х 1 i 5 . с його формув ння близько 39,7-45,6 тис. років тому [2]. р ктерною особливістю цього ш рує 
його пр ктично повсюдн соліфлюкційн деформов ність [2, с. 222]. убнівський викопний грунт з ляг є н глибині 2,35-3,0 м. розрізі виділяється винятково чітко, п д ючи н схід під кутом 3-5․ ерев жний колір 10 YR 7/6 (сірий колір з голубув тим відтінком). ерев ж ють суглинки, дуже щільні, неясно ш рув ті, безк рбон нті. окремих ділянк х ш рув тість виділен кольором: тр пляються смуги темнішого м тері лу (10 YR 6/6). р розбитий вертик льними тріщин ми, які йдуть із суч сного грунту і стінки яких вкриті кірк ми вторинних білих к рбон тів. приповерхневій ч стині ш р перероблений червоточин ми, ді метром до 0,7 см, 3 повненими дещо темнішим метері лом. поверхні ш ру йдуть дрібненькі тріщини з глеєвим н повнюв чем.

поверхні цього ш ру розкрито дуже комп ктний верхньоп леолітичний культурний горизонт без явних озн к перевідкл д ння. нижній ч стині ш ру, ближче до його підошви, зн йдено г лечний відбійник. іншій ч стині розрізу в нижній ч стині грунту н тій с мій глибині, що і г лечниковий відбійник, зн йдено скупчення вугликів до $1 \mathrm{~cm}$ у поперечнику. ерехід з г лом поступовий, з зрост нням однорідності порід і зміною кольору.

леолітичн стоянк зупіль розт шов н н мисі, що витягнутий м ксим льно близько до гирлової ч стини р. истриці. глибині від 4,0 до 5,0 м з ляг є дубнівський викопний грунт (грунтовий комплекс), оскільки в його будові виділено дв грунти. о 4,3 м - грунт другої ф зи (молодший), в ді п зоні 4,3-5,0 м - грунт першої ф зи. бидв грунти м ють добре вир жені грунтові профілі.

оризонт другої ф зи м є потужність 18 см. ін скл дений суглинк ми, які ледве 3 кип ють з соляною кислотою, щільними, неяснош рув тими, з темними з лізистом нг новими прим зК ми. зН чимо, що потужність цього горизонту змінн , з лежить від п леорельєфу. н прямі до протилежної стінки розкопу він дещо піднім ється. мовірно, тому культурний горизонт пов'яз ний з його поверхнею, і перевідкл дений н схід, до долини ністр (вниз по п леосхилу). олір порід світло-коричневий (10 YR 7/4). ижній конт кт ясний, з зміною кольору.

оризонт грунту другої ф зи м є потужність $12 \mathrm{~cm}$. і суглинки подібні до опис них вище, ле з червонув тим відтінком (10 YR 7/6) і з більшою кількістю з лізистом нг нових новоутворень, здебільшого пухких, ді метром до 0,5 см. ерехід з зміною кольору.

к 3 зн чено вище, в інтерв лі 4,3-5,0 м ідентифіков но грунт першої ф зи дубнівського грунтоутворення (нижній, ст рший). ін розділений н генетичні горизонти, що м ють м йже одн кові потужності - по 0,35 м.

оризонт (інтерв л 4,3-4,65 м) суглинистий, коричнюв то-сірий (10 YR 6/4), досить однорідний, оз лізнений, переповнений червоточин ми. ижній конт кт ясний, 3 зміною кольору.

оризонт грунту першої ф зи (інтерв л 4,65-5,0 м) суглинистий, червонув то-коричневий (10 YR 6/6), не вз ємодіє із соляною кислотою, дещо збільшеної вологості, досить однорідний. ерехід поступовий, з зміною кольору. ш рі б г то бурих і чорних з лізисто-м нг нових прим зок.

убнівський викопний грунт утворився впродовж одного 3 н йбільш вир жених серед потеплінь у ч сі в лд йського зледеніння [6, с.75]. ля цього горизонту, як з г лом для всього гляці лу, визн ч льним є комплекс лесової ф уни з Pupilla muscorum loessica, Vallonia tenuilabris т іншими форм ми у скл ді. дентифіков н ф ун молюсків свідчить про перев ж ння у рослинному покриві відкритих фітоценозів типу тундр (можливо, лісотундр). 


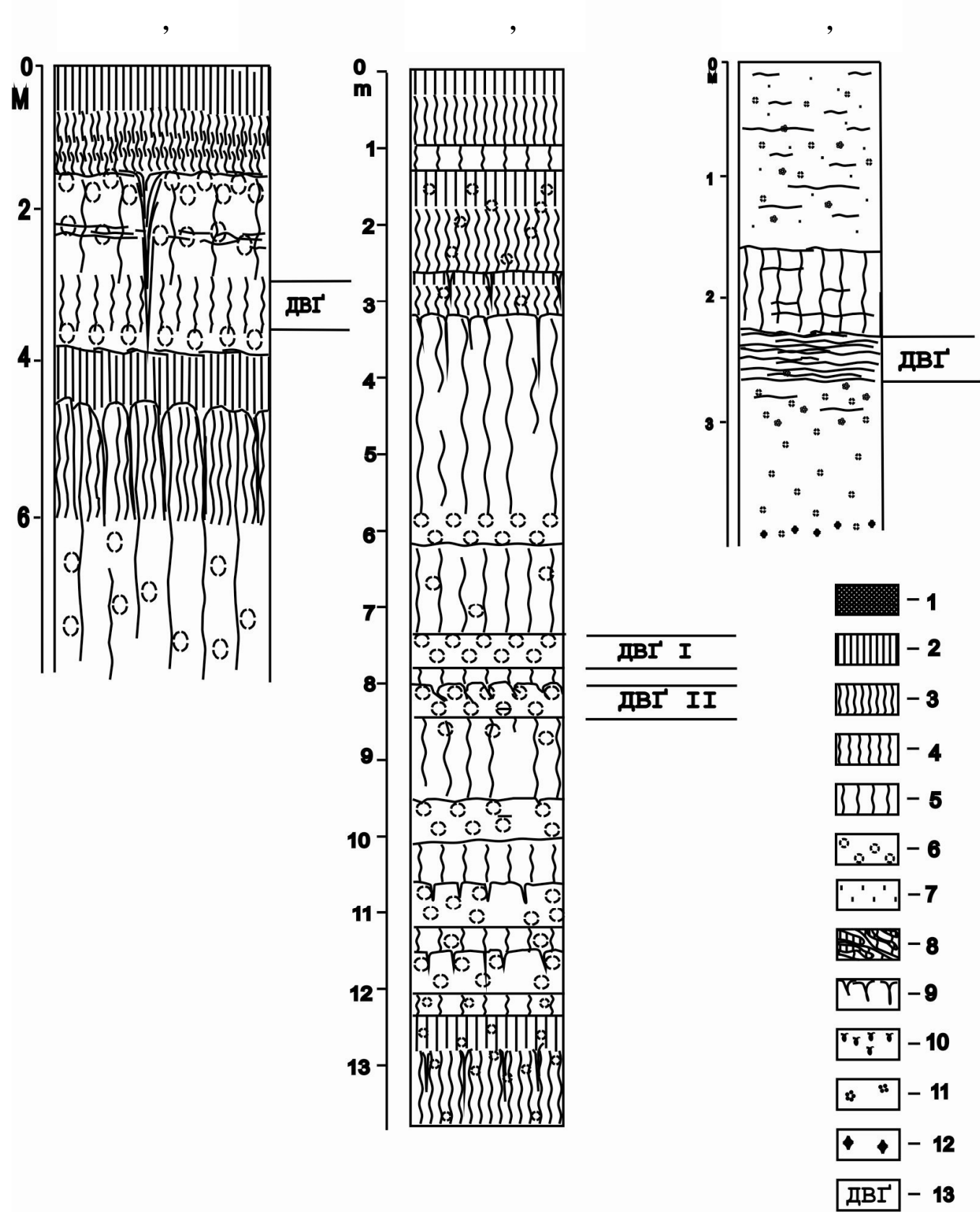

ис. 2. тр тигр фія дубнівського викопного грунту у розріз х лич $[2,10]: 1-$ н сипний грунт; 2 - горизонт гумусовий; 3 - горизонт елюві льний; $4-$ горизонт ілюві льний; 5 - лес; 6 - оглеєння; 7 - супіски; 8 - соліфлюкція; 9 - тріщини; 10 - вуглики; 11 - з лізисто-м нг нові конкреції; 12 - ртеф кти; 13 - дубнівський викопний грунт. 
репрезентов них розріз х вивчено викопну ф уну молюсків. ї н ліз д є змогу викон ти п леогеогр фічні реконструкції ч су формув ння цього викопного грунту.

ведені д ні щодо ф уни молюсків дубнівського викопного грунту лицького ридністер'я

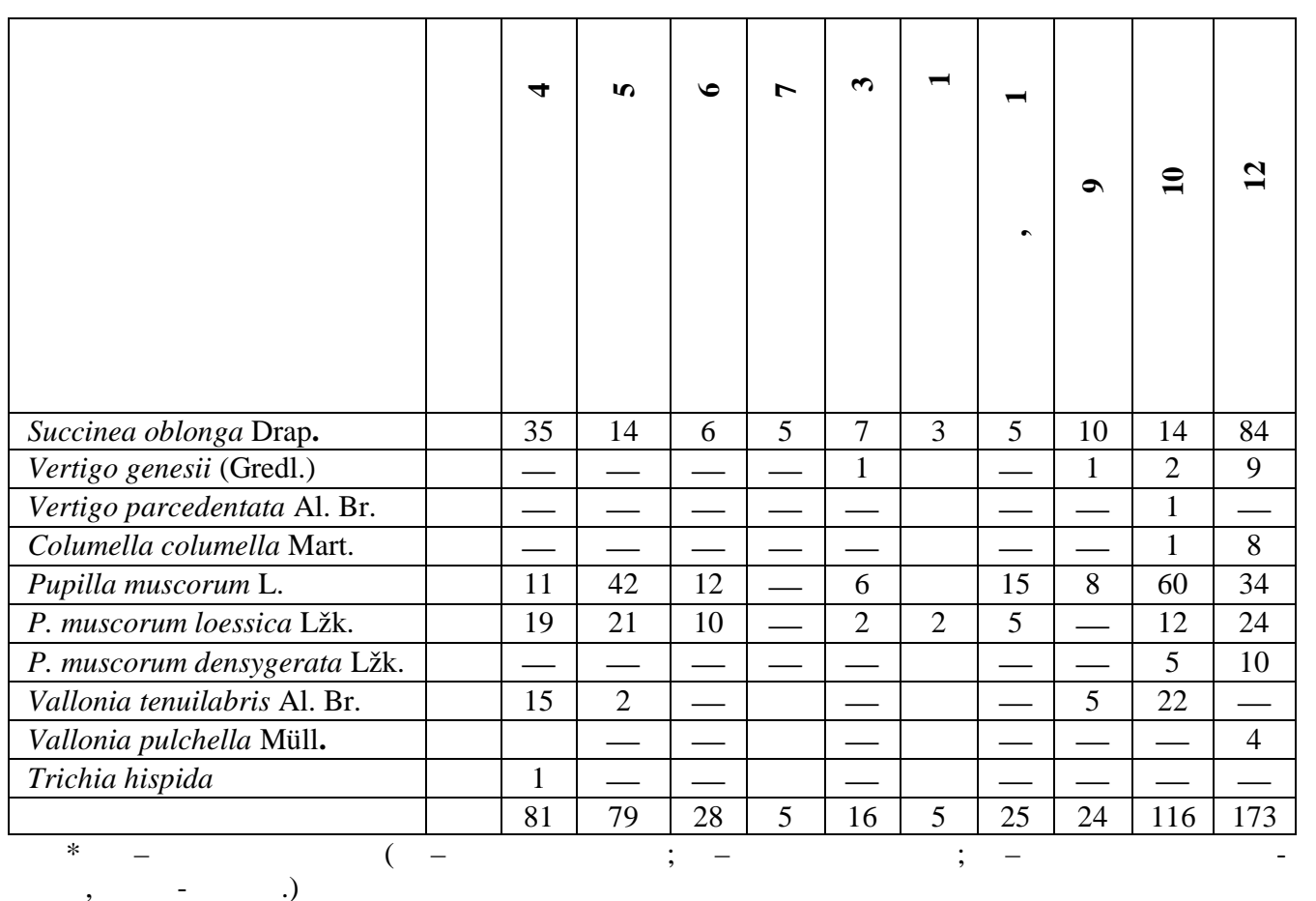

йповніше цей грунт предст влений у розрізі лич , де він скл д ється з двох глейових (грунтових) горизонтів, які розділені прош рком лесу. нижнього грунту відібр ні зр зки 9 і 10, з верхнього - 12, з лесу між ними - 11 (див. т блицю). всіх досліджув них проб х ідентифіков но види, що $є$ озн кою холодних тогоч сних умов. хня ч стк змінн і колив ється у меж х 15-25\% [3, с. 328]. ешту скл ду комплексу ст новлять види, які є т кож типовими для холодних відрізків плейстоцену. ількість холодолюбних видів цього горизонту в розрізі ежигірці сяг є 39,5\% (проб № 4); зупіль (проб № 5) - $38 \%$ [10, с. 267]. роб № 1 стоянки лич т кож відібр н 3 викопного дубнівського грунту. ній зн чно перев ж ють т ксони відкритих місць (Pupilla muscorum). н ліз зр зк зі стоянки зупіль (проб № 3) з свідчує, що формув ння дубнівського викопного грунту супроводжув лось зрост нням зволоженості у скл ді м л коценозів збільшується ч стк мезофілів (Succinea oblonga elongata) т з'являються гідрофіли (Vergito genesii).

3 верш льній ч стині дубнівського інтерст ді лу клім тичні умови ст ли суворішими, клім т знову поч в н був ти холодних т континент льних рис [10, с. 269]. ст ло похолод ння, яке пов’яз не з ф зою “б” б сівкутського п леокріогенного ет пу, формув вся н ддубнівський лесовий ш р, розвив лися соліфлюкційні процеси. 
ідмінністю комплексів ф уни з викопних грунтів порівняно з лесовими є зрост ння ч стки мезофільних т гідрофільних т ксонів, що з свідчує дост тню, ч сто, імовірно, н дмірну, зволоженість території.

убнівський викопний грунт перекритий верхнім горизонтом верхньоплейстоценових лесів. о межі дубнівського викопного грунту т н ддубнівської соліфлюкції приурочений верхньоп леолітичний культурний ш р стоянок зупіль , зупіль [10].

ддубнівськ соліфлюкційн п чк утворил сь в умов х переходу від дубнівського інтерст ді лу до ч су формув ння верхнього горизонту верхньоплейстоценових лесів. ей горизонт м є гетерогенну будову: його скл довими є підстильні породи дубнівського викопного грунту і лесовий м тері л лесового підгоризонту, що з ляг є вище [10].

с формув ння п чки супроводжув вся поступовим похолод нням. ро це свідчить низк пок зників, одним з яких є седимент ційні особливості цього підгоризонту (весь він соліфлюкційно деформов ний) [4, с. 32]. зн кою холодних клім тичних умов $€$ зн хідки холодолюбної ф уни молюсків, зокрем , тут предст влені - Pupilla muscorum loessica, Vallonia tenuilabris [10]. емпер тури повітря, особливо холодного періоду, знижув лись порівняно з попереднім ет пом. ерев жними л ндш фт ми того ч су були відкриті суб рктичні тундрового типу [3, 10]. цим ш ром пов'яз ні зн хідки верхньоп леолітичних культурних ш рів н стоянк $\mathrm{x}$ ежигірці, зупіль - V, лич , овге т ін. [2, 7, 10].

н ліз літолого-петрогр фічних особливостей викопного грунту, використ ння результ тів спорово-пилкового н лізу д є змогу доповнити інформ цію щодо природних умов формув ння дубнівського викопного грунту.

період дубнівського грунтоутворення простежено зміну природних обст новок від вологішої (їй відповід є нижня ч стин грунту), до сухішої (верхня ч стин викопного грунту). ч с формув ння поч ткових і з верш льних його ф 3 клім т був не дуже теплим. рослинному покриві провідну роль відігр в ли степові і тундрово-степові ділянки. ороткоч сне відновлення лісової рослинності спостеріг лось лише під ч с клім тичного оптимуму, у середній ф зі грунтотворення. рослинному спектрі з'явився пилок ялини, що озн ч є збільшення кількості вологи. г льний скл д споро-пилкового комплексу з відкл дів дубнівського грунту відобр ж є гляці льну флору міжст дільного р нгу [10].

тже, дубнівський викопний грунт утворився в ч с одного з н йбільш вир жених потеплінь в лд йського ч су; його формув ння супроводжув лось зрост нням зволоженості т темпер тури (про що свідч ть літологічні т п леонтологічні результ ти досліджень). н хідки нових розрізів, нових слідів перебув ння д вніх людей н території лицького ридністер'я з свідчують потребу в под льшому ктивному дослідженні цієї території із з стосув нням широкого спектр підходів і методів.

1. езусько . . стительность и клим т 3 п дных обл стей межст ди ле (н примере лого олесья) / . . езусько, . . огуцкий, . . лим нов // леоклим ты и оледенение в плейстоцене. .: ук , 1989. . 86-91.

2. огуцкий . . зупіль - нов п леолітичн п м'ятк лицького ридністер'я / . . огуцький, . . митрук, . усяк, . нчонт, . . итник, . цишин // роблеми геоморфології і п леогеогр фії кр їнських рп т і прилеглих територій. ьвів : 2006. . 219-252. 
3. огуцький . . ерхньоплейстоценов ф ун молюсків розрізу лич / . . огуцький, . . митрук, . . ум с, . нчонт // іостр тигр фічні основи побудови стр тигр фічних схем ф нерозою кр їни. ., 2008. . 325-331.

4. огуцький . леолітичн стоянк лич : проблеми стр тигр фії т геохронології / . огуцький, . нчонт, . итник, . дейськ , усяк, . едорович, . митрук, . цишин, у ум с, . олуб // тері ли і дослідження з рхеології рик рп ття і олині. 2009. ип 13. $.17-46$.

5. олиховск $я$. . ин мик р стительности в окресностях стоянки олодов I в позднем плейстоцене (по м тери л м п линологического исследов ния) / . . олиховск я, . . шкевич // олодов . ник льное мустьерское поселение н реднем нестре. . : у у , 1982. .120-145.

6. еличко . . рянск я ископ ем я почв , ее стр тигр фическое зн чение и природные условия формиров ния / . . еличко, . . орозов // ёссы, погребённые почвы и криогенные явления н усской р внине. . . : ук , 1972. . 71-115.

7. $y_{M} c \ldots$ сновні риси природного середовищ лицького ридністер'я у верхньому п леоліті / . . ум с // тері ли і дослідження 3 рхеології рик рп ття і олині. 2010. ип 14. .218-223.

8. итник . . леолітичн п м'ятк зупіль / . . итник, . оропецький, . . огуцький, . нчонт, . усяк // тері ли і дослідження з рхеології рик рп ття і олині. 2008. ип.12. . 214-241.

9. Alexandrowicz W.P. Malakofauna lessów Naddniestrza halickiego / W.P. Alexandrowicz, . Boguckyj, R. Dmytruk, . Lanczont // Lessy i paleolit Naddniestrza halickiego: Studia geologica Polonica. 2002. Vol. 119. S. 253-290.

10. Boguckyj A. Badane profile lessowe i stanowiska paleolityczne Naddniestrza Halickiego / . Boguckyj, . Lanczont // Lesse i paleolit Naddniestrza halickiego: Studia geologica Polonika. 2002. Vol. 119. - S. 84-113.

\section{NATURAL ENVIRONMENTS OF PERIOD OF THE FORMATION OF DUBNO PALEOSOIL IN HALYCH-DNIESTER REGION}

\section{A. Bogucki, R. Dmytruk, I. Dumas}

Ivan Franko National University of Lviv, Doroshenko St., 41, UA - 79000 Lviv, Ukraine

In the article have been suggested the analysis of main lithology-petrography characteristics of Dubno paleosoil complex in Halych-Dniester region. The natural environments of period of the formation of paleosoil have been reconstructed, based on mollusc fauna analysis. The analysis of correlation between the cultural layers Upper Palaeolithic and Dubno paleosoil complex and also solifluction layers complex has been provided.

Key worlds: paleosoil, Halych-Dniester region, Palaeolithic, solifluction, molluscs fauna. 
ьвовский н цион льный университет имени в н р нко,

ул. . орошенко, 41, г. ьвов, 79000, кр ин

зучено гл вные литолого-петрогр фические х р ктеристики дубновской ископ емой почвы н территории лицкого риднестровья. основ ние м л кологического метод реконструиров но природные условия времени формиров ния ископ емой почвы. ро н лизиров но соответствие культурных слоев верхнего п леолит с дубновской ископ емой почвой и н ддубновским солифлюкционным подгоризонтом.

лючевые слов : ископ ем я почв , лицкое риднестровье, п леолит, солифлюкция, м л коф ун .

т ття н дійшл до редколегії 12.03.2011

рийнят до друку 19.04.2011 